\title{
Learners of Italian as L2 and the Awareness of the Cultural Connotation of Words
}

\author{
Rita Scotti Jurić \\ Juraj Dobrila University of Pula/Pola \\ rscotti@unipu.si
}

Durante l'apprendimento dell'italiano L2 è importante l'aspetto dell'acquisizione del lessico che comprende sia il significato denotativo che connotativo. In particolare quello connotativo è spesso arbitrario e culturalmente specifico; riconoscerlo diventa un prerequisito della competenza interculturale. Tale conoscenza dovrebbe essere accessibile agli studenti di italiano in Istria, dato che il contatto con la lingua deriva dall'ambiente stesso. Nell'intento di verificare quest' ipotesi sono stati inclusi nella ricerca studenti delle scuole medie e superiori. La ricerca si pone i seguenti obiettivi: dove avviene il contatto con elementi della cultura italiana; quali sono le più frequenti parole ed espressioni che gli studenti associano con la cultura italiana; quanto efficace risulta l'insegnamento dell' italiano L2 in Istria e a che livello di competenza lessicale arrivano gli indagati nel riconoscere i significati connotativi.

Parole chiave: competenza lessicale nella $\mathrm{L}_{2}$, significato connotativo, significato denotativo, competenza interculturale, italiano, acquisizione del lessico

Pri učenju italijanščine kot drugega jezika je pomemben tudi aspekt usvajanja besedišča, pri čemer je pomemben tako denotativi kot tudi konotativni pomen. Sploh konotativni je pogosto arbitraren in kulturno-specifičen, njegovo prepoznavanje pa je predpogoj za pridobitev medkulturne kompetence. Tovrstno znanje naj bi bilo dosegljivo učečim se italijanščine na dvojezičnih področjih v Istri, saj je stik z drugim jezikom zagotovljen v samem okolju. Z namenom preveriti to hipotezo so biliv raziskavo vključeni učenci predmetne stopnje osnovne šole in dijaki srednjih šol. Raziskava želi raziskati kje se učenci in dijaki srečujejo z elementi italijanske kulture; katere so najpogostejše besede in fraze, ki jih učenci in dijaki asocirajo z italijansko kulturo; koliko je učinkovito poučevanje italijanščine kot drugega jezika v Istri in kakšno stopnjo leksikalne kompetence imajo sodelujoči pri prepoznavanju konotativnega pomena.

Ključne besede: leksikalna kompetenca v drugem jeziku, konotativni pomen, denotativi pomen, interkulturalna kompetenca, italijanščina, učenje besedišča

T he code model of communication, used from Aristotle till the modern age, aimed to analyze or build the discourse through message codification and decodification. Following that perspective, the meaning of the utterance would be completely and inwardly codificated and the communicative process would not request any interpretative creativity. Reversely, numerous researches, which are placed half way between the philosophy of speech, pragmalinguistics and cognitive sciences, put an emphasis on the importance and the determinant role, in the communicative contexts, played by intentions and the inferential processes. These are communicative effects where the meaning of communication is regarded to be a form of cooperative social interaction based upon knowledge sharing (Grice, 1975; Sperber 
\& Wilson, 1986; Lewis, 1979; Watzlawick et al.,

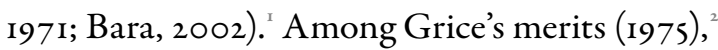
there is the introduction of the inferential mod$e l$, which contrasts the code model of communication. His model considers communication as a process in which the addressee of the message (receiver, listener, or hearer) has to rebuild the meaning of the utterance produced by the addresser (speaker), not relying much on what he says but on what his communicative intensions actually were. The inferential processes convey the interpretation of meaning and the concept of context, intended as "the set of premises used in interpreting an utterance" (Sperber and Wilson, 1986, p.15), ${ }^{3}$ assumes a role of primary importance. In that optics, in order to achieve a successful speech act, the speaker "who intends an utterance to be interpreted in a particular way must also expect the hearer to be able to supply a context which allows that interpretation to be recovered" (Sperber \& Wilson, I986, p.I6) ${ }^{4}$. Once the narrow relationship between language and context had been identified, the pragmatic theories took the direction towards the twofold studies of the effect of utterances on the context and the effects of the context on the meaning of words and expressions. Our research interest deals with the second direction, according to which "we cannot understand the exact meaning of an utterance drawing only on syntactic or semantic roles because, at a certain point, we need to use contextual information in different ways". The American semiologist Charles W.

\footnotetext{
Paul Grice, "Logic and Conversation," in Syntax and Semantics: Speech Acts, Vol. 3, eds. P. Cole and J. L. Morgan (New York: Academic Press, 1975), 41-58; Dan Sperber and Deirdre Wilson, Relevance: Communication and Cognition (Oxford: Blackwell, 1986); David Lewis, "Scorekeeping in a Language Game," Journal of Philosophical Logic, 8(1979): 339-359; Paul Watzlawick, Janet Helmick Beavin and Donald deAvila Jackson, Pragmatica della comunicazione umana. Studio dei modelli interattivi, delle patologie e dei paradosi (Roma: Astrolabio, 1971); Bruno Bara, Pragmatica cognitiva. I processi mentali della comunicazione (Torino: Bollati Boringhieri, 2002).

Grice, "Logic and Conversation," 4I-58.

Sperber and Wilson. Relevance: Communication and Cognition.

Sperber and Wilson. Relevance:Communication and Cognition.

Eleonora Farina and Ottavia Albanese, "Making Inferences and Individual Differences in Emotion Understanding," Psychology of Language and Communication, II (2) (2007): 4 .
}

Morris ${ }^{6}$ proposed his threefold divisions of semiotics in syntax (the study of mutual formal relations of signs), semantics (the study of relations of signs with objects to which they are applicable) and pragmatics (the study of the relation of signs with those who interpret them). In this paper, the focus is put on the last two sectors, the semantic and the pragmatic ones, aiming to contribute to the study of lexic and phraseology, a discipline that has recently detected the importance of phraseological elements in discourse analysis for the development of the speakers' intercultural communicative competence in a language.

\section{From the lexical competence}

in the $12 / f$ to the communicative intercultural competence

Dell Hymes" introduction of the concept of communicative competence marked a decisive reversal in the field of language acquisition studies. According to the author, besides the linguistic competence perceived as knowledge of the normative system of rules in the target language, learners develops a sociolinguistic competence which enables them to use the language in different communicative contexts in an appropriate way. ${ }^{8}$ The perspective and the terminology introduced by Hymes have been resumed by lots of authors, becoming a part of the theoretical justifications of the new communicative approach within the field of language teaching. It is astonishing that this kind of orientation "turned to the know how to deal with a language, does not correspond at the same time to the reflection of the semantic-lexical aspects, essential for gaining communicative competence". 'The first systematic approach to the study of lexis goes back

\footnotetext{
6 Charles Morris, Lineamenti di una teoria dei segni (Torino: Paravia, 1970).

Dell Hymes, "Models of the interaction of language and social setting," Journal of Social Issues 23(2) (1967): 8-38; Dell Hymes, "On Communicative competence," in Sociolinguistics: Selected Readings, eds. J. B. Pride and J. Holmes, (Harmondsworth: Penguin, 1972), 269-293.

Hymes, "On Communicative competence," 269-293.

Mario Cardona, "L'insegnamento e l'apprendimento del lessico in ambiente CLIL. Il CLIL e l'approccio lessicale. Alcune riflessioni," Studidi Glottodidattica, 2 (2009): 2.
}

(19)

4


to the last decades of the 2 oth century. Besides the intensification of publications on the learning and teaching of lexis, we also experienced a multiplication of theories, reference models and terminological systems often inconsistent and discordant. In general, the debates and the theoretical discussions concerning the lexis are focused in particular on the study of the concept of lexical competence, on the nature and structure of mental lexic, on the strategies of lexical learning, on the role played by the individual differences and the context of learning. According to the theorethical assumptions, scholars agree about considering lexical competence, or the ability to acquire, produce and interpret the connotative meaning of words and expressions, as a key factor for achieving intercultural competence in the $\mathrm{L}_{2} / \mathrm{FL}$. Considering the interactional settings, the knowledge of the norms of the target culture sharpens the dialogical intercultural competence (Morlicchio, 2002). ${ }^{\text {10 }}$ Let us consider the whole set of lexical units, idiomatic phrases and expressions, metaphors and routinized forms used in everyday interactions, all deeply immersed in idiomaticity (Cardona, 2008), ${ }^{11}$ with which the learner of a L2/FL has to deal before (s)he interiorises the norms and grammatical structures of the target language. According to Bachman (1990), ${ }^{12}$ a determinant aspect of the sociolinguistic competence resides in the skill of using and interpreting the cultural references and the figures of the spoken language. The author underlines that "the conventions governing the use of figurative language as well as the specific meanings and images that are evoked, are deeply rooted in the culture of a given society or speech community". "That is shown in all the words having a strong cultural connotation, which in different languages convey different

Io Elda Morlicchio, "Plurilinguismo e interculturalità," in Europa, lingue istruzione primaria, ed. P. Marzotta (Torino: UTET, 2002), 3-29.

Mario Cardona, "La comprensione e produzione di idioms: aspetti psicolinguistici e riflessioni glottodidattiche," Studi di Glottodidattica, 3 (2008): 45-64.

12 Lyle Bachman, Fundamental considerations in language testing (Oxford: Oxford University Press, 1990).

13 Bachman, Fundamental considerations in language testing, 98. meanings and values (Zhao, 2004; Wu \& Dou, 2011). ${ }^{14}$ Lexical competence implies the knowledge of the semantic borders that each word in the target language contains, as well as various pragmatic aspects assumed in the speech acts and the conversational implications in relation to the context and the interlocutors. Therefore, semantics is integrated with pragmatics, which is the study of the usage of language in context.

\section{Connotative and denotative meaning}

The absence of a common theoretical basis of reference for the study of lexis and lexical competence in $\mathrm{L}_{2}$ /FL leads to a terminological confusion, due partially to the nature of the studied phenomenon. Besides the notion of lexical competence in relation to the adopted approach (semantic, pragmatic, psycholinguistic, glottodidactic and so forth), there are other relevant concepts such as: metaphoric competence, intended as the ability to acquire, produce and interpret the methaphoric speech in the target language (Littlemore, 200I; Littlemore \& Low, 2006) ${ }^{15}$ and figurative competence, which assumes the ability to comprehend and produce metaphors, idiomatic forms and figurative speech in general (Levorato, 1993). ${ }^{16}$ At the same time, there is a frequent indistinct use of terms related to the same conceptual sector, but not always assimilable, including: metaphorical speech, idiomatic expressions, formulaic language usage, figurative speech, idioms, connotations, etc. To overcome the absence of the theoretical and the conceptual basis of reference, it has been decided to incorporate the concepts listed above under the more

I4 Jun Zhao, "EFL Students' Awareness of Cultural Connotations of Words," Arizona Working Papers in SLAT, II (2004): 37-55; Shujing Wu and Tongpei Dou, "An Experimental Study on Transfer of Cultural Connotation of Vocabulary," Cross cultural Communication, 7 (2011): 97-III.

I5 Jeannette Littlemore, "Metaphoric Competence: A Language Learning Strenght of Students With a Holistic Cognitive Style?" TESOL QUARTERLY, 35(3) (2001): 459-491; Jeannette Littlemore and Graham Low, "Metaphoric competence and communicative language ability," Applied Linguistics, 27 (2) (2006): 268-294.

16 Chiara M. Levorato, "The Acquisition of Idioms and the Development of Figurative Competence," in Idioms: Processing, Structure and Interpretation, eds. C. Cacciari and P. Tabossi (Hillsdale, N.J.: Lawrence Erlbaum Associates, 1993), 101-128. 
generic notion of connotative meaning that, in the acceptation assigned to it by Geoffrey Leech, represents "the communicative value an expression contains by virtue of what it refers to over and above its purely conceptual content". ${ }^{17}$ Different from the denotative meaning (conceptual or cognitive) that can be codified "in terms of limited sets of symbols ${ }^{38}$ and is therefore stable and shared by the entire linguistic community, the connotative meaning is polysemic and open, often carrying social and cultural values. Lyons underlined that "many of the concepts with which we operate are culture-bond in the sense that they depend for their understanding upon socially trasmitted knowledge, both practical and propositional and vary considerably from culture to culture". ${ }^{19}$ Traditionally, the approach to lexis teaching privileged the isolated and decontextualised teaching of words and expressions, sticking in particular to their denotative meaning. While on one hand, “/../ word-centered vocabulary teaching is suitable for helping the learner to construct the cognitive contents (representations) that are typical of the $\mathrm{L}_{2}{ }^{2},{ }^{\circ}$ on the other hand, that approach neglects the teachings of any of the prefabricated structures, traditionally called expression, phrase, utterance, whose constituent elements are not replaceable or recombinable following the current language rules (Mazzotta, 2002). ${ }^{21}$ The absence of that structural knowledge, which is deemed as a poor referential appropriateness (Corder, 1983), ${ }^{22}$ leads to a cultural overlap in the field of language acquisition.

\footnotetext{
17 Geoffrey Leech, Semantics: The Study of Meaning (Harmondsworth: Penguin Books, 1985), I2.

I 8 Leech, Semantics: The Study of Meaning, I3.

19 John Lyons, Language and Linguistics. An introduction (Cambridge: Cambridge University Press, 1981), 308.

20 Moises Almela and Aquilino Sánchez, "Words as 'Lexical Units' in Learning/Teaching Vocabulary," International Journal of English Studies, 7 (2007), 36 .

2 I Patrizia Mazzotta, "Le direttive della Comunità Europea per l'insegnamento delle lingue," in Europa, lingue e istruzione primaria. Plurilinguismo per il bambino italiano-europeo, ed. Patrizia Marzorra (Torino: UTET, 2002).

22 Pit S. Corder, Introduzione alla linguistica applicata (Bologna: Il Mulino, 1983).
}

\section{The research}

Goals

Taking into account the theoretical reflections reported in the previous pages, we conducted a research with the following aims:

a) to investigate the centers of interest in which the middle and secondary school students find elements regarding Italian culture with higher frequency;

b) to determine which words and expressions are associated with the centers of interest identified by the participants;

c) to inquire the degree of lexical competence of the participants, that is their ability to identify the connotative meanings of words;

d) to analyse the effectiveness of linguistic and cultural education of Italian L2/FL in Istria for the development of an intercultural communicative competence.

\section{Methodology and subjects}

The tool used for data collection was a sociolinguistic questionnaire with the aim to obtain information regarding extradidactic factors involved in the motivation for intercultural studies, attempting to detect the conscious reasons and causes that arouse the speaker's interest for different languages and cultures. As for that, it was investigated where learners find, during their everyday school activities, elements linked to Italian culture. The preliminary part of the sociolinguistic questionnaire was submitted to 259 Istrian middle school students ( $152 \mathrm{fe}$ males $=58.7 \%$ and 107 males $=4 \mathrm{I} .3 \%)$ and 522 Istrian secondary schools students $(343$ females $=65.7 \%$ and 179 males $=34.3 \%)$ in Pula/Pola, Buje/Buie, Poreč/Parenzo, Umag/Umago, Pazin/Pisino, Žminj/Gimino and Labin/Albona. The middle school students were aged from in to I 4 years and the secondary school students from I5 to I8 years. After the detection of the main categories that supplied information about the intercultural competences, the survey shifted to the second part of the research which measured 
the semantic competence in the Italian language during the activities in the classroom, with the intention to discover the degree of intercultural immersion of the subjects. The first activity included the detection of lexems that broaden the centers of interest contained in the sociolinguistic test. The teachers stimulated the research with the following questions: If I tell you "Italian history", what do you tell me? Or: What can you tell me about Italian history and religion, about music, food and Italian material items? What do you recall? The second activity performed in the classes requested an analysis of lexems detected, focusing on the capacity to identify the connotative meanings of the concepts and the pragmalinguistic discoursive functions. They were mainly mental activities developing in the field of open and informal learning, not closely linked to school and taxonomic teachings, careful about linguistic code grammaticality. Therefore, the possible connotations, hyponyms/hyperonyms, metaphors, idiomatic expressions and proverbs were identified, obviously, in the cases where the lexems offered that possibility. The two lexical - semantic activities included fewer students, which were sampled in the middle schools (four grades) and the secondary schools (four grades) indicated above.

\section{Data analysis \\ Sociolinguistic analysis}

First of all, we tried to clarify to the students the meaning of the concept intercultural education, which recognizes cultural differences as a positive value and a resource for a learning characterized by the capacity of decentralization of one's own point of view, aiming to stregthen the formation of a more dynamic identity, able to converse with any form of otherness. The cultural entries like writing, music, fairy tales, and games are surely the starting points for the intercultural learning paths of a great impact and effectiveness. In addition, the following question was asked: "During the regular activities performed in the classroom, where have you met elements regarding the lifestyle of other cultures?" The partic- ipants answered as follows: $55.6 \%$ of the middle school students met elements regarding the lifestyle of other cultures through listening to music and through the material world items, represented by various objects of current usage (46.7\%). A minor percentage met the elements of other cultures in the rituals described in history texts and in the study of religions (37,5\% and 35,5\%). Only $23,2 \%$ of the students met elements of culture in different kinds of food, $17,4 \%$ of them in games and $15,4 \%$ in fairy tales. A non neglectable number of students affirmed to have met the elements of lifestyle of other cultures on the Internet, in the sports and videogame spheres. The data are shown in Figure I.

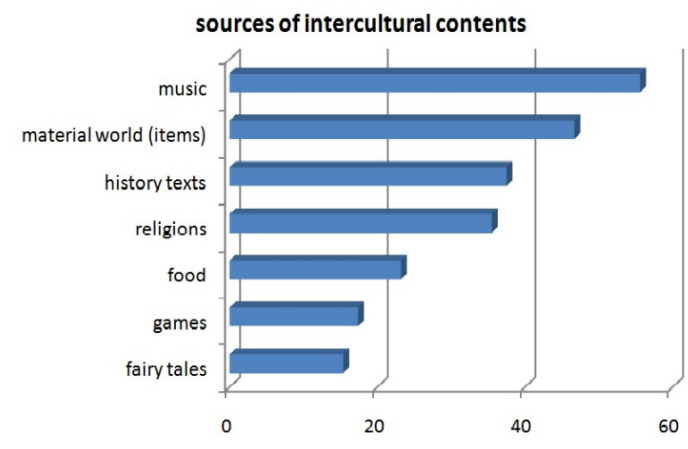

Figure I. Intercultural contents in middle schools

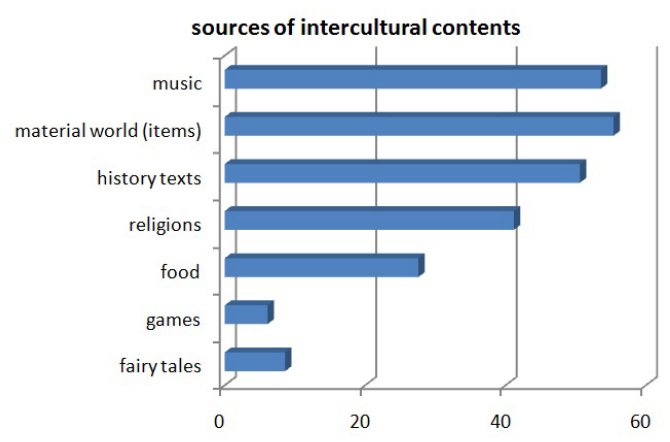

Figure 2. Intercultural contents in secondary schools

Answering the same question, a notable percentage of secondary school students bears in the first place the possibility for a manifestation of cultures through material world of common and everyday usage and through music, with the percentage being $55.4 \%$ and $53.6 \%$. Not distant 
were also the opinions stating that the rituals described in history texts and the study of religions enable the direct contact with elements of other cultures (50.6\% and 41.2\%). Less importance was given at the intermediary role of particular types of food, the reading of fairy tales and games $(27.6 \% ; 8.65 \%$; 6.1\%).

The first reflection developed afterwards is focused primarly on an operative point of view. The underlying problem is not only related to updating and enriching the cultural contents, possibly by adding more texts concerning foreign cultures or providing a greater quantity of information regarding foreign costumes and traditions. A lesson of culture and civilization may undertake ambitious and very informative programs and may face important fields of study, like literature, politics, law or artistic traditions of a country. However, it does not free the learners from the arousal of related questions. We should not reflect upon the quantity and quality of information, but on the modality to present and inquire them.

The results of the sociolinguistic test were interpreted in relation to the variable of the place (zone) of origin of the participants. The analysis showed an interesting situation. The Istrian peninsula was devided in four zones of origin: $\mathrm{I}$. the southern zone (Pula-Pola), 2. the western zone (Buje-Buie, Poreč-Parenzo, Umag-Umago), 3. the eastern zone (Labin-Albona), 4. the central zone (Pazin-Pisino, Žminj-Gimino). As shown in Table I, the school activities of middle schools where the students encountered intercultural elements evidenced as statistically significant $(p<.00 \mathrm{I})$ were compared in the following results, on the basis of the four zones of reference:
Table ı. School activities that promote interculturality in middle schools

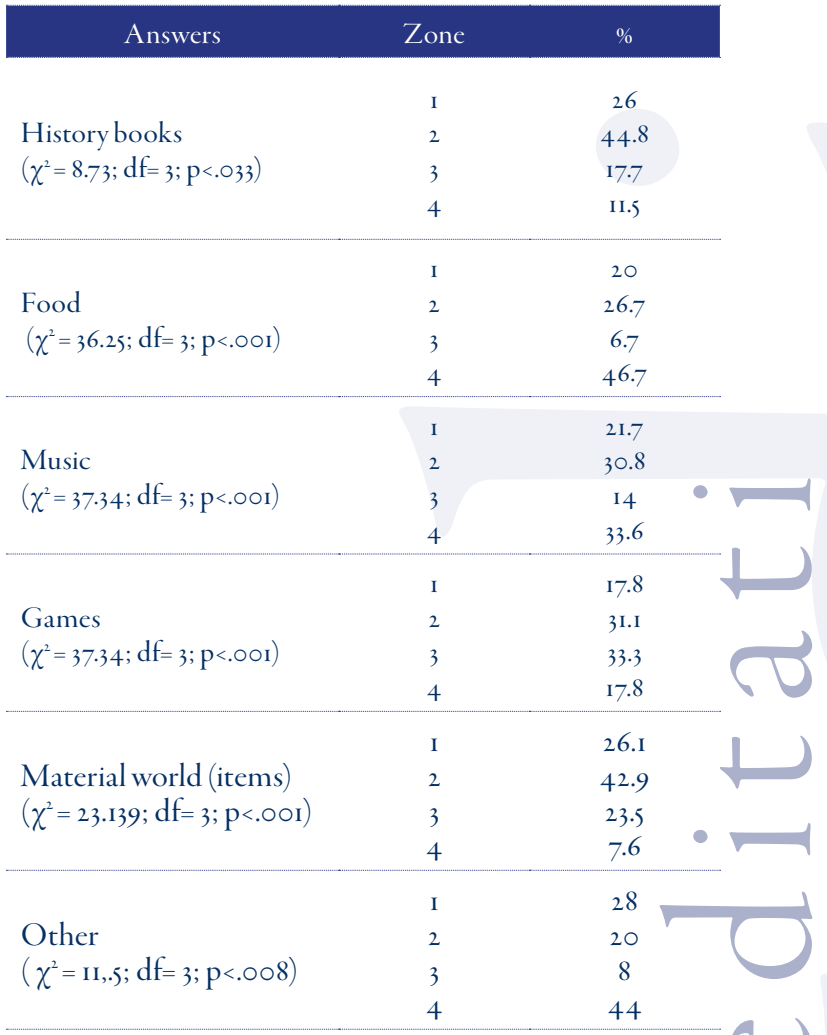

Concerning the opinion of the students of western Istria middle schools, in the cities of $\mathrm{Bu}$ je-Buie, Umag-Umago and Poreč-Parenzo, they seemed to attribute an essential value to history textbooks as major contributors for divulging interculturality. In central Istria, in the town of Pazin-Pisino, it was claimed that food and music belong to the most meaningful topics for gaining a satisfactory degree of interculturality of the school population. The interculture seemed to be manifested even through games and habits of people in plurilingual places. Therefore, the participants from Labin-Albona and eastern Istria recognized themselves particularly in those acitivities. Morever, western Istria recognized interculturality through the use and presence of culturally marked objects. The students in the central part stated that there are other elements that guarantee the access to different cultures. 
None decisive singular opinion aroused from southern Istria (Pula-Pola and surroundings).

The situation of secondary schools is shown in the following table.

Table 2. School activities that promote interculturality in secondary schools

\begin{tabular}{lcc}
\multicolumn{1}{c}{ Answers } & Zone & $\%$ \\
Games & I & 53.1 \\
$(\chi 2=16.019 ; \mathrm{df}=3 ;$ & 2 & 21.9 \\
$\mathrm{p}<.001)$ & 3 & 9.4 \\
& 4 & 15.6 \\
Materi- & $\mathrm{I}$ & 28.4 \\
alworld (items) & 2 & 41.5 \\
$(2=40.953 ; \mathrm{df}=3 ;$ & 3 & 27.3 \\
$\mathrm{P}<.00 \mathrm{I})$ & 4 & 2.8 \\
& &
\end{tabular}

As can be seen, the differences among the zones are particularly evident: in the zone of $\mathrm{Pu}$ la-Pola there were $53.1 \%$ of votes given to the entry "games", while the eastern zone of Labin-Albona did not approve the same idea (9.4\%). It can be supposed that in the memory storage of students in Pula-Pola and surroundings, there was an emersion of a higher certainty based on the importance of play (game) meetings for a more active manifestation of interculturality. On the other hand, the youth of the eastern zone regarded playing as an internationalized and universal activity not having local characteristics and expressions any more, perhaps too often referred to as the entertainment of the new media, like the Internet and various softwares. Another relevant difference, concerning the importance of material world items in reaching intercultural competence during lessons of Italian $\mathrm{L}_{2}$, aroused between the western (41.5\%) and the central zone (2.8\%).

\section{Lexical-semantic analysis}

The data obtained from the sociolinguistic analysis were certainly indicative, but not sufficient to identify which would be the most "prolific" center of interest, and whether the semantic competence of students justified the answers expressed in the questionnaire. For that reason, the students were submitted to acitivities that detected the concrete lexical-semantic competence of the most popular intercultural centers of interest. In that sense, we skipped the entries "fairy tales" and "games", because they were reported as less meaningful for the sociolinguistic test. Different from the formal linguistic competences, the intercultural competences, which embrace the acquisition of contents, values, opinions of the $\mathrm{C}_{2}$, cannot be quantified. Trying to find the procedures able to evaluate the degree of the reached intercultural competence, even without the support of the consolidated theories, we moved on the track of the Council of Europe indications (200I), ${ }^{23}$ trying to find the possible traces in the evaluation of semantic fields, including phraseology. The original idea aroused from the certainty that the development and training of linguistic abilities shall never be proposed nor pursued as purpose to themselves, but as tools of a richer participation to social and intellectual life. The training of the verbal abilities should always be motivated within the study activities, research, discussion, participation, and individual and team production. For that reason, our first activity investigated the intercultural knowledge, intended as the capacity to identify the meanings, information and connotations present in the "other" culture. By means of asking such questions as "What can you say about Italian history/religion/food/music/material items?", or "If I tell you - Italian history/Italian religion/...- what do you think of?", I managed to structure the five centers of interest in their constituent parts (Table 3 ). All the centers of interest arouse cultural connotations applicable to every single inquired sphere. The sources for their knowledge are mainly school handbooks and everyday communication with their Italian teachers.

23 Council of Europe, Common European Framework of Reference for Languages: Learning, teaching, assessment (Cambridge: Cambridge University Press, 2001). 
Table 3. Intercultural centers of interest in middle schools

History fascismo, l'Impero Romano, Romolo e Remo,
l'Arena (il Colosseo), Cesare Imperatore,

Religion Il Vaticano, il Papa, la Madonna, gli angeli, San

Antonio di Padova, Roma, la croce

La pizza, il panettone, la Nutella, i tortellini, le lasagne, gli spaghetti, pasta verde, il parmigiano, panettone
Materi-

alworld

(items)

La gondola, il Colosseo, il braccialetto/la catenina d'oro, la moda italiana, le automobili

Table 4. Intercultural centers of interest in secondary schools

Il Risorgimento, gli etruschi, la famiglia Medici, Garibaldi, Vittorio Emanuele, Benito Mussolini, i Romani, storia dell'arte, Michelangelo, il ducato (moneta di Venezia), Cesare Augusto, la la-

History tinità, il fascismo, la seconda guerra mondiale, la fondazione di Roma, la Lupa Capitolina, la civiltà etrusca, Cosimo de Medici, Giuseppre Garibaldi, le Camicie Rosse, la mafia, la camorra, Vittorio Emanuele II,

La processione, Mosè, la basilica di San Pietro, Piazza San Pietro, il papa, il Vaticano, i preti, la Cappella Sistina, le catacombe, il Cristia-

Religion nesimo, le crociate, i francescani, i benedittini, San Francesco, Sant'Antonio di Padova, Assisi, Sant'Agostino, il Concilio di Trento, Piazza San Pietro, Santa Caterina da Siena, Francesco d'Assisi, Natale, Ponzio Pilato, la Messa
La pasta alla bolognese, i ravioli, le frittole, il parmigiano reggiano, i tortellini, la mortadella, la pizza, le tagliatelle, il ragù, la Nutella, il torrone, la minestra, il formaggio, il cavolo, le penne, olio d'oliva, pesto alla genovese, la ciambella, la mozzarella, il tiramisù, l’arancia rossa di Sicilia, le tagliatelle di nonna Enrica, le lasagne, il panettone, la colomba

Laura Pausini, Eros Ramazzotti, l'opera buffa, Gioacchino Rossini, Jovanotti, Ramazzotti, Giuseppe Verdi, Adriano Celentano, il festival

Music di Sanremo, l'opera, La Fenice, la Scala, Luciano Pavarotti, Nek, Ballando con le stelle, Andrea Boccelli, Zucchero, Antonio Vivaldi, il canto gregoriano, i trovatori, Giuseppe Verdi, Puccini, Rigoletto, Fratelli d'Italia, il melodramma, Materi- $\quad$ li Fiat, Alfa Romeo, Lamborgini, Gucci, Ferrè, alworld Valentino, Arlecchino, la gondola, Lancia, Fer(items) rari, la Monna Lisa, abigliamento Armani, Dolce e Gabbana, mobili cucine Scavolini

As seen in Table 3 and Table 4 , overall, in the four grades inquired, the youth of the middle schools mentioned just around 30 concepts linked to Italian culture and Italianity, which shows a rather lacking intercultural competence. The students of the four grades of the secondary schools mentioned around 130 units, a considerable number of elements, which confirms a solid knowledge of Italian culture. If that knowledge was able to become intercultural competence during the interaction among speakers, we could affirm that among the youth attending secondary school and willing to attend university, there is a meaningful intercultural competence in progress. Later in life, the willingness to deepen their competence will depend upon their individual affinities. Obviously, the five centers of interest represent just the first sample and perhaps not the most meaningful one. We are conscious that there are even other centers of interest that could have been tested, like sports, which would have certainly offered many other intercultural implications. In that sense, this paper is just the first attempt to investigate the degree of intercu- 
lurality offered in Istrian plurilingual and pluricultural classrooms.

Table 5. Lexical connotations

In casa mia c'è un regime fascista.

Questa scuola è diventata un lagher.

History

Ogni popolo ha avuto il proprio Cesare.

Tutte le strade portano a Roma.

Abbiamo pagato alla romana.

Il papa è qualcosa di unico, singolare, importan-

te. La sua morte è

un evento eccezionale.

Morto un papa se ne fa unaltro.

Sono malato ogni morte del papa.

Vado a teatro ogni morte del papa.

Non sei mica il papa.

Lungo come una messa cantata.

Lungo come la Quaresima.

Religion

Lavarsi le mani come Pilato.

Facevano a testa e croce per decidere chi sarebbe sceso a bussare

alla sua porta.

Ormai ci ho messo una croce sopra.

Suo padre faceva tutto da bravo benedettino. Freddie Mercury è stato definito il dio del rock.

Il tuo è davvero uno scherzo da prete.

Vivere in santa pace.

Devei avere santa pazienza per sopportarla.

Non tutte le ciambelle riescono con il buco.

Che pizza il film di ieri!

Che pizza ragazzi!

Mario non sapeva nuotare ma aveva una ciambel-

la di materiale

gonfiabile per mantenersi a galla.

Quel ragazzo è di buona pasta.

Di che pasta sei?

È molto importante lavarsi i denti con la pasta dentifricia.

Ma che fico che è tuo fratello!

Non vale un fico secco.

Non me ne importa un cavolo.

Questi sono cavoli miei.

Ci ho quasi lasciato le penne!

Mi ha spiegato tutto con un atteggiamento melodrammatico.

È ora di cambiare musica ragazzi!

Finalmente l'assassino ha cantato!

Loro hanno sempre avuto un tenore di vita molto elevato.
After having investigated the denonative sphere of the selected centers of interest, the research moved to the identification of their connotative values. Students were asked to show a few connotations, perhaps some hyponyms or hyperonyms, idiomatic phrases and figures of speech (metaphor, metonymy, antonomasia, hyperbole), in order to identify the acceptation that a polysemic word takes on in a text and trace all the other possible meanings. Particulary interesting were the idiomatic expressions that belong to the so called "cultural implicits" of a language. They had been identified and analysed keeping the students aware of the fixed order of elements and the fact that the meanings of an idiomatic expression, a way of saying or a particular narrow collocation, are never equal to the sum of the meanings of the single words. In fact, the expression assumes in its whole a figurative-metaphoric sense. The data obtained from both school levels inquired (middle and secondary schools) show an additional ability to shift from the code model (semantic) to the inferential and pragmatic one. The lexical connotations for the centers of interest identified by the sociolinguistic test, expressed in the communicative and pragmatic form, were set around the figurative meanings reported in Table 5 .

Regarding the centers of interest bound to the material world items that denote the presence of Italian culture, expressions that would show an effective and intercultural use had not been found. That kept a trace of doubt on the results of the first sociolinguistic questionnaire that considered the material world items on top of the graded list in the opinions of middle and secondary schools, in particular as for what concerns the western zone of Istria. The lexical-semantic research confirmed instead the results of the sociolinguistic research regarding the centers of interest "Italian history". Actually, the participants in the western zone (zone 2), in the localities of Buje-Buie, Poreč-Parenzo and Umag-Umago indicated a higher number of cultural connotations of words and expressions linked to history in comparison to the participants of oth- 
er zones. It seems that the inquired youth of the western zone lived more intensively their intercultural contacts with italophone speakers and it could be supposed that their lexical competence resulted from a major familiarity with the Italian mass media. Additionally, concerning the centers of interest "food" and "music", the results obtained in the central zone (zone 4), including

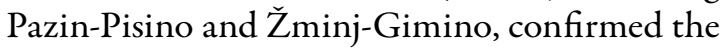
sociolinguistic data that regarded them to be at the top of the long list of words and respective connotations provided for the centers of interest in question. As the central zone of Istria is almost totally croatophone, such a competence of the students is explainable with a good didactic practice sensible to the teaching of culture and elements of the Italian civilisation.

\section{Discussion and conclusion}

With this research we wanted to investigate the degree of lexical competence of Istrian middle and secondary school students, studying Italian as $\mathrm{L}_{2} / \mathrm{FL}$. The starting point of the conducted study was the theoretical assumption according to which the ability to aquire, produce and interpret the connotative meaning of words and expressions, and the capacity to identify the pragmatic functions assumed in concrete linguistic speech acts, are of primary importance for the development of the intercultural communicative competence. Semantics is therefore integrated with pragmatics, i.e. with the study of language use in context.

As for the first aim of the research, which investigated the centers of interest in which students met elements regarding Italian culture with major frequency, it emerged from the results that the participants recognized them mostly in primary resources of elements and knowledge bound to the various aspects of Italian culture, such as the spheres of music, material world, food, history and religious texts.

The aim of the first lexical-semantic activity was to determine which words and expressions were associated to the centers of interest identified by the participants. With the ques- tion "What can you say about italian history/religion/food/music/material world items?", or "If I tell you Italian history/Italian religion"... what do you think of?" we managed to structure the five centers of interest in their constituent parts. Overall, it emerged from the results that middle school students expressed just around 30 concepts linked to Italian culture and Italianity, which shows a rather lacking intercultural competence. Secondary school students mentioned instead around 130 items, a number that states a solid base of knowledge of Italian culture.

An additional lexical-semantical activity was proposed, at the end, to investigate the degree of lexical competence of the participants, i.e. the ability to identify the connotative meanings of the lexical units listed for the various centers of interest. It emerged from the results that all the centers of interest arouse cultural connotations related to every single investigared sphere. Above all, even though there were a few difficulties showed by the participants in finalizing the issued activity, the slight quantity of collected data seems worth particular attention. In spite of having a fair knowledge of the Italian language lexis, the learners were not educated to put them in relation to the old and new acquaintances, or to construct a net of words being always ready to provide information. As could have been seen, the learning of new meanings represents the enriching of the net of acquaintance. Broadening one's own lexis does not mean just adding new information to the given container, but even new links and inferences among the old ones. The functionality of language (or its capacity to transmit information, a thought, a feeling, and so forth in an adequate way), as has been seen, does not depend only on the choice of words, which was shown to be particularly fair and after all satisfying in the first part of our semantic-lexical research. The message is made understandable, clear, and, from time to time, more economic by particular models of structural organization (examined in the second part of the lexical-semantic research). 
The last aim of the research was to analyze the effectiveness of linguistic and cultural education of Italian as the language of social environment $\left(\mathrm{L}_{2}\right)$ in Istria, for the development of intercultural communicative competence. The didactic strategy presented promotes intercultural linguistic teaching that departs from the centers of interest (clear and defined key concepts) and it articulates them in their constitutent parts with the suggestions coming from semantics and pragmatics. The methodology used started from the certainty that the pure semantic competence, intended as the recipient of words from which the speaker should draw in order to proceed with the distribution, is not decisive for a better communicative competence. If language conveys culture, then the semantic study is not separable from the pragmatic one, in particular way regarding its functional side. The linguistic-functional disadvantages of the inquired youth of the research denote a habit of teachers to go beyond the classic presentation of vocabulary in purely denotative terms. That phenomenon is more and more connotated as a linguistic and expressive risk of the Italian language and therefore stresses the necessity of a deeper reflection.

The continuous comparison that the student is obliged to trace, between his own meanings and the ones of the linguistic environment where he lives, produces gradually two decisive changes in his lexis: first of all, from the point of view of the semantic content, he undertakes little by little meanings that are common to other speakers, which is the knowledge shared and used by all of them who live in a foreign environment. Secondly, from the point of view of the semantic structure, it transforms the aggregate of specific and separated notions in an organic system of general concepts, putting them into relation one with the other, according not only to individual criteria. The intercultural approach considers the learning of the $\mathrm{L}_{2}$ as the encounter beetween two cultures and the possibility to modify the attitudes of the learner. The study of culture becomes one with the study of lan- guage, contributing to the formation and the intellectual growth of the student and his identity (Council of Europe, 200I). ${ }^{24}$ Waiting for the directives for an intercultural linguistic education elaborated for the countries members of the EU, this first investigation shows the state of progress of intercultural abilities of students and their degree to mediate between the cultures. The latter represents a hint for the elaboration of strategies that lead to a sensibilization and development of the interaction with the $\mathrm{C}_{2}$.

\section{Summary}

Second language vocabulary acquisition depends on the teaching of not only a word's denotative, but also connotative meaning. The latter is often arbitrary and culture-specific and its recognition is a precondition for achieving an intercultural competence. The second language learner has to deal with meaning, gradually developing the awareness of denotative and connotative properties of words and idiomatic expressions. It is assumed that such a stimulus is provided to Italian as a second language in multilingual and multicultural Istria, given that the learners are immersed into an environment rich with Italian language and cultural events. In order to test the hypothesis, the study included middle and secondary school students from Istria. The research had four main aims: to investigate the centers of interest in which the middle and secondary school students find elements regarding Italian culture with higher frequency; to determine which words and expressions students associate with certain areas of interest related to Italian culture; to analyse the effectiveness of linguistic and cultural education of italian L 2 in Istria for the development of an intercultural communicative competence; to inquire the degree of lexical competence of the participants, that is their ability to identify the connotative meanings of words. The results showed that secondary school students nominated a significantly greater number of words and expressions associated with the given areas of interest, while both groups were faced with substantial difficulties in determining their connotative meanings.

24 Council of Europe, Common European Framework of Reference for Languages: Learning, teaching, assessment. 


\section{Povzetek}

Usvajanje besedišča v drugem jeziku je odvisno od učenja ne samo denotativnega pač pa tudi konotativnega pomena. Ravno drugi tip pomena je pogosto arbitraren in kulturno-specifičen, njegovo prepoznavanje pa je predpogoj za pridobitev medkulturne kompetence. Kdor se uči drugega jezika, se mora lotiti tudi učenja pomena in v povezavi z njim razvijati zavedanje o denotativnih in konotativnih lastnostih besed in idiomatskih fraz. Predpostavljamo, da je tovrstno znanje dosegljivo učečim se italijanščine kot drugega jezika v večjezični in večkulturni Istri, kajti okolje, v katerem se nahajajo, omogoča stik z italijanskim jezikom in s kulturnimi dogodki v tem jeziku. Z namenom preveriti to hipotezo so bili v raziskavo vključeni učenci predmetne stopnje osnovne šole in dijaki srednjih šol iz Istre. Raziskava ima štiri glavne cilje: preučiti centre v katerih se učenci in dijaki zelo pogosto srečujejo z elementi italijanske kulture; ugotoviti katere besede in fraze učenci in dijaki asocirajo z interesnimi področji povezanimi z italijansko kulturo; analizirati učinkovitost jezikovnega in kulturnega poučevanja italijanščine kot drugega jezika v Istri z namenom razvoja medkulturne sporazumevalne kompetence; preučiti stopnjo leksikalne kompetence sodelujočih preko ugotavljanja njihove sposobnosti, da prepoznajo konotativni pomen besed. Rezultati kažejo na to, da so učenci in dijaki imenovali veliko večje število besed in fraz, ki jih asocirajo z interesnimi področji, medtem ko sta se obe skupini soočali s težavami pri določanju konotativnega pomena.

\section{Bibliography}

Almela, Moises and Sánchez, Aquilino. "Words as 'Lexical Units' in Learning/Teaching Vocabulary." International Journal of English Studies, 7 (2007): 2I-40.

Bachman, Lyle. Fundamental considerations in language testing. Oxford: Oxford University Press: 1990.

Bara, Bruno. Pragmatica cognitiva. I processi mentali della comunicazione. Torino: Bollati Boringhieri: 2002.

Cardona, Mario. "La comprensione e produzione di idioms: aspetti psicolinguistici e riflessioni glottodidattiche." Studi di Glottodidattica 3 (2008): 45-64.
Cardona, Mario. “L'insegnamento e l'apprendimento del lessico in ambiente CLIL. Il CLIL e l'approccio lessicale. Alcune riflessioni." Studi di Glottodidattica, 2 (2009): I-I9.

Corder, Pit S. Introduzione alla linguistica applicata. Bologna: Il Mulino, 1983.

Council of Europe. Common European Framework of Reference for Languages: Learning, teaching, assessment. Cambridge: Cambridge University Press, $200 \mathrm{I}$.

Farina, Eleonora and Albanese, Ottavia. "Making Inferences and Individual Differences in Emotion Understanding." Psychology of Language and Communication, II(2) (2007): 3-19.

Grice, Paul. "Logic and Conversation." In Syntax and Semantics: Speech Acts (Vol. 3), eds P. Cole and J. L. Morgan (Eds.), 4I-58. New York: Academic Press, 1975.

Hymes, Dell. "Models of the interaction of language and social setting." Journal of Social Issues, 23(2) (1967): $8-38$.

Hymes, Dell. "On Communicative competence." In Sociolinguistics: Selected Readings, eds. J. B. Pride and J. Holmes, 269-293. Harmondsworth: Penguin, 1972 .

Leech, Geoffrey. Semantics: The Study of Meaning. Harmondsworth: Penguin Books, 1985.

Levorato, Chiara M. "The Acquisition of Idioms and the Development of Figurative Competence." In Idioms: Processing, Structure and Interpretation, eds. C. Cacciari and P. Tabossi, IOI-I28. Hillsdale, N.J.: Lawrence Erlbaum Associates, 1993.

Lewis, David. "Scorekeeping in a Language Game.” Journal of Philosophical Logic, 8 (1979): 339-359.

Littlemore, Jeannette. "Metaphoric Competence: A Language Learning Strenght of Students With a Holistic Cognitive Style?" TESOL QUARTERLY, 35(3) (2001): 459$49 \mathrm{I}$.

Littlemore, Jeannette and Low, Graham. "Metaphoric competence and communicative 
language ability." Applied Linguistics, 27(2) (2006): 268-294.

Lyons, John. Language and Linguistics. An introduction. Cambridge: Cambridge University Press, I98I.

Mazzotta, Patrizia. "Le direttive della Comunità Europea per l'insegnamento delle lingue." In Europa, lingue e istruzione primaria. Plurilinguismo per il bambino italiano-europeo, ed. Patrizia Mazzotta, 3-29. Torino: UTET, 2002.

Morlicchio, Elda. "Plurilinguismo e interculturalità." In Europa, lingue e istruzione primaria. Plurilinguismo per il bambino italiano-europeo, ed. Patrizia Marzotta, 79-Io6; 178-182. Torino: UTET. (2002).

Morris, Charles. Lineamenti di una teoria dei segni. Torino: Paravia, 1970.

Sperber, Dan and Wilson, Deirdre. Relevance: Communication and Cognition. Oxford: Blackwell, 1986.

Watzlawick, Paul, Beavin, Janet H. and Jackson deAvila, Donald. Pragmatica della comunicazione umana. Studio dei modelli interattivi, delle patologie e dei paradosi. Roma: Astrolabio, 1971.

Wu, Shujing and Dou, Tongpei. "An Experimental Study on Transfer of Cultural Connotation of Vocabulary." Cross cultural Communication, 7 (2OII): 97-III.

Zhao, Jun. "EFL Students' Awareness of Cultural Connotations of Words." Arizona 